\title{
Physicochemical Properties of Native and Heat Moisture Treated Starches of White and Red Cocoyam (Colocasia esculenta) Varieties
}

\author{
Olukayode Adediran Okunade ${ }^{1, a, *}$, Olanrewaju Arinola ${ }^{1, b}$ \\ ${ }^{1}$ Department of Food Science \& Technology Federal Polytechnic Ado-Ekiti, Ekiti State, Nigeria \\ *Corresponding author \\ A R T I C L I N F O A B S T R A C T \\ Research Article \\ White and red cocoyam starches were physically modified by heat moisture treatment at 16, 24 and \\ $32 \%$ moisture levels. The functional and pasting properties of the modified and native starches \\ were evaluated using standard methods. The swelling power at $60^{\circ} \mathrm{C}$, water absorption capacity, oil \\ absorption capacity, least gelation concentration, packed bulk density and loose bulk density of heat \\ Received : 24/05/2019 \\ Accepted : 23/11/2020 \\ moisture treated white and red cocoyam starches ranged between $1.90-2.18$ and $1.89-2.21 ; 1.00$ \\ $-1.80 \mathrm{ml} / \mathrm{g}$ and $0.80-1.60 \mathrm{ml} / \mathrm{g} ; 1.40-1.80 \mathrm{ml} / \mathrm{g}$ and $1.20-1.40 \mathrm{ml} / \mathrm{g} ; 8.00-10.00 \%$ and $8.00-$ \\ $10.00 \% ; 0.51-0.62 \mathrm{~g} / \mathrm{ml}$ and $0.54-0.64 \mathrm{~g} / \mathrm{ml} ; 0.41-0.51 \mathrm{~g} / \mathrm{ml}$ and $0.43-0.53 \mathrm{~g} / \mathrm{ml}$ respectively. \\ For both white and red cocoyam starches, heat moisture treated starches at $16 \%$ moisture content \\ level had the highest swelling power in the temperature range $60^{\circ} \mathrm{C}$ to $90^{\circ} \mathrm{C}$; also starches treated at \\ $32 \%$ moisture level had the highest water absorption capacity, oil absorption capacity, packed bulk \\ Keywords: \\ Cocoyam starch \\ Heat processing \\ Physicochemical properties \\ Starch modification \\ Starch granules \\ density and loose bulk density. Red cocoyam native starch had higher peak, trough, breakdown, \\ final and setback viscosity than white cocoyam starch. Heat moisture treatment generally increased \\ the pasting properties of white cocoyam starch. The modification of red cocoyam starch at moisture \\ levels of $16 \%$ and $24 \%$ reduced the pasting properties, however at higher moisture level, the pasting \\ properties increased. These results suggest that moisture level of cocoyam starches influence their \\ physicochemical properties during heat moisture modification; this will increase the array of food \\ products in which the starches can be used.
}

\section{Introduction}

Cocoyam is essentially a starchy staple even though reports has it that it has nutritional advantage due to its higher protein content and amino acid than any root/tuber crops (Obiegbuna et al., 2014). Cocoyam is one of the underutilized tropical crops in Nigeria; its cultivation still remains at subsistence level despite its rich nutritional profile. Poor acknowledgment of its nutritional quality, presence of toxicants and its susceptibility to pre and post harvest diseases, which reduce storage stability, have been advanced as reasons that make the crop unpopular in food applications (Igbabul et al., 2014). Efforts to improve post harvest processing and utilization of the crop will significantly reduce post harvest loss of cocoyam. One of the ways to maximize utilization of cocoyam is to extract starch from it which can then be used in various food formulations; starch is the main nutritional component of cocoyam.

Starch is a versatile material that is used in many industries for different purposes; it contributes to structure, texture and consistency of processed foods (Xie et al., 2013). Starch is used as thickener, adhesive, encapsulating agent, gelling agent, binding agent. However, the functional properties of natural starch as obtained/extracted from food materials need to be adjusted through modification to make it suitable for use as functional material in industries. Starch modification refers to physical and/or chemical treatment given to starch to make them applicable in food, pharmaceutical, textile and paper industries. Functional properties such as viscosity, swelling, water absorption capacity, gelation, thermal stability and freeze thaw stability are adjusted to desired level through modification. There is the need to modify cocoyam starch as a way of improving its scope of utilization. Heat moisture treatment is one of the physical methods commonly employed to modify starch. The treatment affects the structural arrangements of starch chains within the amorphous and crystalline regions which may influence granules crystallinity, granules swelling, 
leaching of amylose, pasting properties and thermal stability (Klein et al., 2013; Zavareze and Dias, 2011).

The safety and cost effectiveness of physical methods has made them to be preferred to chemical methods. This paper for the first time, examined the influence of moisture levels on the functional and pasting properties of heat moisture treated white and red cocoyam starches. This is with a view to ascertaining the likely characteristics of these starches in food formulations and food processing.

\section{Materials and methods}

\section{Sample}

Freshly harvested matured and blemish free cocoyam corms were procured from Ekiti State agricultural development project (ADP) farm, Ikare Road, Ado-Ekiti, Nigeria. The corms were sorted for wholesomeness, and into white and red varieties.

\section{Starch Isolation}

Cocoyam corms was washed, peeled, cut into small slices and then washed again, the slices was grated and the resulting slurry was mixed with thrice its volume of water, this was then sieved through muslin cloth until the waste solution was clean. The starch suspension was left overnight at refrigerated temperature $\left(4^{\circ} \mathrm{C}\right)$. The suspension was then decanted and the white starch sediment was dried in a hot air oven at $45^{\circ} \mathrm{C}$ for $8 \mathrm{hrs}$, milled into powder, sieved through $0.5 \mathrm{~mm}$ sieve, packaged in a sealed high density polyethylene and stored in glass jars at room temperature $\left(27^{\circ} \mathrm{C}-31^{\circ} \mathrm{C}\right)$.

\section{Heat Moisture Treatment}

Native cocoyam starch with moisture content of $9.97 \%$ was used for the heat moisture treatment using the procedure described by Nadir et al. (2015) with some modifications. Briefly, starch samples were divided into three portions, the moisture content of the three portions were differently adjusted to $16 \%, 24 \%$ and $32 \%$ respectively by adding appropriate amount of distilled water. The three starch samples were well stirred and then heated in sealed glass jars in a hot air oven at $120^{\circ} \mathrm{C}$ for 1hour. The samples were thereafter cooled, air dried to a moisture content of $10 \%$, milled into powder, sieved through $0.5 \mathrm{~mm}$ sieve, packaged in a sealed high density polyethylene and stored in glass jars at room temperature $\left(27^{\circ} \mathrm{C}-31^{\circ} \mathrm{C}\right)($ Nadir et al., 2015).

\section{Evaluation of Starch Yield}

The percentage yields of 2 starches isolated from white and red cocoyam were determined from the weight of cocoyam corms (W1) used and the final weight of starch (W2) obtained.

$$
\text { Yield }(\%)=\frac{\mathrm{W} 2}{\mathrm{~W} 1} \times 100
$$

\section{Analysis of Chemical Properties, Purity and pH}

The native starches of white and red cocoyam were analyzed for their moisture, ash, crude fat (ether extract) and crude protein contents $(\mathrm{N} \times 6.25)$ according to the methods described by AOAC (2005). Amylose content was determined by the iodine binding methods described by Oke et al. (2013). Purity (\%) was calculated by difference $[100$ - $(\%$ crude protein $+\%$ crude fat $+\%$ ash $)]$. $\mathrm{pH}$ was determined according to the method described by Onitilo et al. (2007) with the use of pH meter (Starter 2100 Bench $\mathrm{pH}$ Meter) which had been previously standardized with buffer solution of $\mathrm{pH} 4$ and 9 .

\section{Analysis of Functional Properties}

Swelling power of native and modified starch samples were determined at $60^{\circ} \mathrm{C}, 70^{\circ} \mathrm{C}, 80^{\circ} \mathrm{C}$ and $90^{\circ} \mathrm{C}$ using the method described by Kaur et al. (2011). Water and oil absorption capacities were determined by using the procedure of Sathe et al. (1982). Least gelation concentration was determined by heating the sample suspension $(2-20 \%)$ for 1 hour in boiling water $\left(100^{\circ} \mathrm{C}\right)$ followed by cooling for 2 hours at $4^{\circ} \mathrm{C}$ (Onwuka, 2005). Loose and Packed bulk densities of were determined by using the method of Mpotokwane et al. (2008). The flowability and compressibility of the starches was determined using the Carr index and Hausner ratio. The Carr index (CI) and Hausner ratio were evaluated as shown below:

$$
\begin{gathered}
\text { CI }(\%)=\frac{\text { Packed bulk density-Loose bulk density }}{\text { Loose bulk density }} \times 100 \\
\text { Hausner Ratio }=\frac{\text { Packed bulk density }}{\text { Loose bulk density }}
\end{gathered}
$$

\section{Analysis of Pasting Properties}

The pasting properties notably peak viscosity, trough viscosity, breakthrough viscosity, final viscosity, setback viscosity, pasting temperature and peak time of the native and modified starch samples were determined using Perten Rapid Visco Analyzer (RVA 4500; Perten Instruments, Sweden). A $3 \mathrm{~g}$ flour sample was mixed with $25 \mathrm{ml}$ of water to produce $12 \%(\mathrm{w} / \mathrm{w}$; db) flour suspension in the RVA canister; a paddle was placed into the canister and its blade was jogged through the suspension up and down for about 6 times to ensure proper mixing of the suspension. The canister fitted with the paddle was then inserted in the RVA machine. The 12 minutes profile was used; idle temperature of $50^{\circ} \mathrm{C}$ for 1 minute, sample was heated from $50^{\circ} \mathrm{C}$ to $95^{\circ} \mathrm{C}$ in 3 minutes 45 seconds, held at $95^{\circ} \mathrm{C}$ for 2 minutes 30 seconds and then cooled back to $50^{\circ} \mathrm{C}$ over 3 minutes 45 seconds period followed by a period of 2 minutes when the temperature was maintained at $50^{\circ} \mathrm{C}$.

\section{Statistical Analysis}

The difference in the experimental data was tested for statistical significance $\mathrm{P} \leq 0.05$ by Statistical Analysis of Variance (ANOVA) using SPSS 21.0 software package (Statistical Package for Social Scientist, Michigan, USA).

\section{Results and Discussion}

Yield, Chemical Properties and pH of Native Starches of White and Red Cocoyam Varieties

The yield, chemical properties and $\mathrm{pH}$ of starches of white and red cocoyam varieties are presented in Table 1. The yield of starch of red cocoyam (11.28\%) was significantly higher than that of white cocoyam (9.02\%). Even though the peeling operation was done manually with possibility of variation in the amount of corm removed as 
part of peel, however, the fact that this determination was done thrice with significantly higher starch yield of red cocoyam suggest that the red variety had higher starch content than white variety. The yield values reported in this study was lower than $21.1 \%$ reported by Aprianita et al. (2014), this difference may be due to difference in the basis of determination; Aprianta et al. (2014) determined the starch yield based on the weight of cocoyam flour while the weight of raw corms was used as basis of starch yield determination in the study. The moisture content of the two starches were similar and were comparable with the range (7.76-7.91\%) reported by Himeda et al. (2012) but lower than $10.91 \%$ reported for cocoyam starch by Gbadamosi and Oladeji (2013); the difference may be due to effectiveness of the drying medium and the amount of water molecules that exits in bound or free form. The ash content of starch of white cocoyam was higher than that of red cocoyam; their values were lower than the values ( $1.87 \%$ and $2.01 \%$ respectively) reported for white and red cocoyam starches by Awokoya et al. (2012).

The protein and fat contents of the starches were lower than values reported by Gbadamosi and Oladeji (2013). The low protein and fat contents suggest that they would have limited interference in the properties of starch; protein content below $5 \%$ in starch had been reported to have no significant effect on the thermal properties of starch (Mirmoghtadaie et al., 2009). The white and red cocoyam starches were relatively pure $(96.72 \%$ and $96.95 \%$ respectively); purity of starch, which depends on its ash, protein and fat contents, is influenced by the extent to which non-starch material is removed during the isolation and washing of starch, and the amount of protein, fat and mineral elements that are tightly bound to the starch granules. The amylose content of white cocoyam starch was significantly higher than that of red cocoyam starch; the value reported in this study was higher than $10.1 \%$ reported by Aprianita et al. (2014) but lower than the range, $27.6-35.9 \%$ reported for starch isolated from cocoyam of different maturity stage (Himeda et al., 2012), this difference may be as a result of different varieties of cocoyam. Amylose and amylopectin influenced the water absorption, swelling, viscosity, gelatinization and hydrolysis of starch (Lu et al., 2008). The $\mathrm{pH}$ of both starches were slightly in the acidic region.

\section{Functional Properties, Densities and Flow Characteristics of Starches of White and Red Cocoyam} Varieties
The functional properties, densities and flow characteristics of white and red cocoyam starches are presented in Table 2. The heat moisture treatment of white and red cocoyam starches at $16 \%$ moisture level increased the swelling power of the starches above that of native starch, increase in moisture level above $16 \%$ resulted in the reduction of the swelling power. The reduction in swelling power of heat moisture treated samples when the moisture level exceed $16 \%$ may be attributed to relative increase in interactions involving amylose-amylose, amyloseamylopectin chains and possible transformation of amorphous amylose to helical form at higher moisture level during the heat moisture treatment (Pinto et al., 2015; Chung et al., 2009). Temperature had a prominent effect on the swelling of the cocoyam starches, at temperature above $60^{\circ} \mathrm{C}$, the swelling power of modified white and red cocoyam starches were consistently higher than that of the native starches (Figure 1 and 2). Increase in moisture level during heat moisture treatment generally improved the water and oil absorption capacity of the starches. The increase in water absorption capacity indicates that some hydrogen bonds in the crystalline region of the granules are broken thereby exposing more water absorption site on the starch molecules. Olayinka et al. (2007) had reported that heat moisture treatment induced changes in the crystalline regions of starch granules. The increase in the oil absorption capacity of cocoyam starches as a result of the modification was contrary to the report of Adebowale et al. (2005) on the effect of heat moisture treatment on the oil absorption capacity of red sorghum. The modification method employed in this study did not cause any significant effect on the least gelation concentration of white and red cocoyam starches. The effect of heat moisture treatment on the packed bulk and loose bulk density of cocoyam starches was moisture dependent. For white cocoyam starch, modification at $24 \%$ moisture level reduced the packed bulk and loose bulk density while for red cocoyam starch, packed bulk and loose bulk density were reduced at 16 and $24 \%$ moisture level.

There was no significant difference between the hausner ratio of native and modified white cocoyam starches, however the carr index of modified white cocoyam starch at 16 and $24 \%$ moisture level was significantly higher than that of the native white starch indicating a better compressibility.

Table 1. Yield, Chemical Properties and pH of Native Starches of White and Red Cocoyam Varieties

\begin{tabular}{l|cc}
\hline \multicolumn{1}{c|}{ Components (\%) } & White & Red \\
\hline Yield & $9.02 \pm 1.04^{\mathrm{b}}$ & $11.28 \pm 0.82^{\mathrm{a}}$ \\
Moisture & $7.14 \pm 0.40^{\mathrm{a}}$ & $6.94 \pm 0.32^{\mathrm{a}}$ \\
Ash & $1.56 \pm 0.01^{\mathrm{a}}$ & $1.28 \pm 0.02^{\mathrm{b}}$ \\
Protein & $1.17 \pm 0.04^{\mathrm{a}}$ & $1.09 \pm 0.03^{\mathrm{a}}$ \\
Fat & $0.63 \pm 0.01^{\mathrm{a}}$ & $0.60 \pm 0.01^{\mathrm{a}}$ \\
Amylose & $17.47 \pm 0.38^{\mathrm{a}}$ & $15.68 \pm 0.50^{\mathrm{b}}$ \\
Amylopectin* & $82.53 \pm 1.04^{\mathrm{b}}$ & $84.32 \pm 1.04^{\mathrm{a}}$ \\
pH** & $6.42 \pm 0.01^{\mathrm{a}}$ & $6.30 \pm 0.00^{\mathrm{a}}$ \\
Purity & $96.72 \pm 0.04^{\mathrm{a}}$ & $96.95 \pm 0.03^{\mathrm{a}}$ \\
\hline
\end{tabular}

Values are mean of triplicate determination, Mean values in the same row with different superscript are significantly different $(\mathrm{P} \leq 0.05),{ }^{*}$ Amylopectin value was obtained by difference, $* *$ Not in percentage 
Table 2. Effects of Heat Moisture Treatment on the Functional Properties, Densities and Flow Characteristics of Starches of White and Red Cocoyam (Colocasia esculenta) Varieties.

\begin{tabular}{|c|c|c|c|c|c|c|c|c|c|c|c|}
\hline $\mathrm{C}$ & MO & SP & WAC (ml/g) & $\mathrm{OAC}(\mathrm{ml} / \mathrm{g})$ & $\operatorname{LGC}(\%)$ & PBD & LBD & HR & CI & FL & $\mathrm{CO}$ \\
\hline \multirow{4}{*}{ W } & Native & $1.80 \pm 0.00^{\mathrm{d}}$ & $1.00 \pm 0.00^{\mathrm{bc}}$ & $1.20 \pm 0.10^{\mathrm{cd}}$ & $8.00^{\mathrm{a}}$ & $0.57 \pm 0.01^{b}$ & $0.47 \pm 0.00^{\mathrm{cd}}$ & $1.21^{\mathrm{bcd}}$ & $21.28^{\mathrm{b}}$ & $\mathrm{F}$ & $\mathrm{F}$ \\
\hline & $\mathrm{HMT}_{16}$ & $2.18 \pm 0.02^{\mathrm{ab}}$ & $1.20 \pm 0.10^{\mathrm{b}}$ & $1.40 \pm 0.10^{\mathrm{bc}}$ & $8.00^{\mathrm{a}}$ & $0.62 \pm 0.02^{\mathrm{a}}$ & $0.50 \pm 0.00^{\mathrm{abc}}$ & $1.24^{\mathrm{ab}}$ & $24.00^{\mathrm{a}}$ & $\mathrm{F}$ & G \\
\hline & $\mathrm{HMT}_{24}$ & $1.90 \pm 0.01^{\mathrm{cd}}$ & $1.00 \pm 0.10^{\mathrm{bc}}$ & $1.60 \pm 0.20^{\mathrm{ab}}$ & $10.00^{\mathrm{a}}$ & $0.51 \pm 0.00^{c}$ & $0.41 \pm 0.00^{\mathrm{f}}$ & $1.24^{\mathrm{ab}}$ & $24.39^{\mathrm{a}}$ & $\mathrm{F}$ & G \\
\hline & $\mathrm{HMT}_{32}$ & $2.00 \pm 0.01^{b c}$ & $1.80 \pm 0.20^{\mathrm{a}}$ & $1.80 \pm 0.10^{\mathrm{a}}$ & $8.00^{\mathrm{a}}$ & $0.62 \pm 0.01^{\mathrm{a}}$ & $0.51 \pm 0.00^{\mathrm{ab}}$ & $1.22^{\mathrm{abc}}$ & $21.57^{\mathrm{b}}$ & $\mathrm{F}$ & $\mathrm{F}$ \\
\hline \multirow{4}{*}{$\mathrm{R}$} & Native & $2.15 \pm 0.02^{\mathrm{ab}}$ & $1.00 \pm 0.10^{\mathrm{bc}}$ & $1.00 \pm 0.10^{\mathrm{d}}$ & $8.00^{\mathrm{a}}$ & $0.57 \pm 0.02^{\mathrm{b}}$ & $0.48 \pm 0.00^{\mathrm{bcd}}$ & $1.19^{\mathrm{cd}}$ & $18.75^{\mathrm{c}}$ & G & $\mathrm{P}$ \\
\hline & $\mathrm{HMT}_{16}$ & $2.21 \pm 0.01^{\mathrm{a}}$ & $1.20 \pm 0.10^{\mathrm{b}}$ & $1.20 \pm 0.10^{\mathrm{cd}}$ & $10.00^{\mathrm{a}}$ & $0.54 \pm 0.00^{\mathrm{bc}}$ & $0.46 \pm 0.00^{\mathrm{de}}$ & $1.17^{\mathrm{d}}$ & $17.39^{c}$ & G & $\mathrm{P}$ \\
\hline & $\mathrm{HMT}_{24}$ & $1.89 \pm 0.10^{\mathrm{cd}}$ & $0.80 \pm 0.10^{\mathrm{c}}$ & $1.40 \pm 0.10^{\mathrm{bc}}$ & $10.00^{\mathrm{a}}$ & $0.54 \pm 0.01^{b c}$ & $0.43 \pm 0.00^{\mathrm{ef}}$ & $1.26^{\mathrm{a}}$ & $25.58^{\mathrm{a}}$ & $\mathrm{F}$ & G \\
\hline & $\mathrm{HMT}_{32}$ & $1.91 \pm 0.01^{\mathrm{cd}}$ & $1.60 \pm 0.20^{\mathrm{a}}$ & $1.40 \pm 0.10^{\mathrm{bc}}$ & $8.00^{\mathrm{a}}$ & $0.64 \pm 0.02^{\mathrm{a}}$ & $0.53 \pm 0.00^{\mathrm{a}}$ & $1.21^{\mathrm{bcd}}$ & $20.76^{\mathrm{b}}$ & $\mathrm{F}$ & $\mathrm{F}$ \\
\hline
\end{tabular}

C: Cultivar, MO: Modification, SP: Swelling Power @ 60 C, PBD: Packed Bulk Density (g/ml), LBD: Loose Bulk Density (g/ml), HR: Hausner Ratio, CI: Carr Index (\%), W: White, R: Red, FL: Flowability, CO: Compressibility, F: Fair, G: Good, P: Poor, Values are means of triplicate determination, Mean values in the same column with different superscript are significantly different $(\mathrm{P} \leq 0.05)$, WAC: Water absorption capacity, OAC: Oil absorption capacity, LGC: Least gelation concentration

Table 3. Effects of Heat Mositure Treatment on the Pasting Properties of Starches of White and Red Cocoyam (Colocasia esculenta) Varieties

\begin{tabular}{c|lccccccc}
\hline C & MO & PV & TV & BV & FV & SV & PT & PS \\
\hline \multirow{5}{*}{ W } & Native & $3687^{\mathrm{e}}$ & $2213^{\mathrm{d}}$ & $1474^{\mathrm{c}}$ & $3595^{\mathrm{e}}$ & $1382^{\mathrm{e}}$ & $4.87^{\mathrm{a}}$ & $84.05^{\mathrm{a}}$ \\
& $\mathrm{HMT}_{16}$ & $4390^{\mathrm{a}}$ & $2738^{\mathrm{a}}$ & $1652^{\mathrm{ab}}$ & $4262^{\mathrm{b}}$ & $154^{\mathrm{c}}$ & $4.67^{\mathrm{b}}$ & $81.65^{\mathrm{d}}$ \\
& $\mathrm{HMT}_{24}$ & $3803^{\mathrm{d}}$ & $2310^{\mathrm{c}}$ & $1493^{\mathrm{c}}$ & $3628^{\mathrm{e}}$ & $1318^{\mathrm{f}}$ & $4.67^{\mathrm{b}}$ & $82.50^{\mathrm{c}}$ \\
& $\mathrm{HMT}_{32}$ & $4065^{\mathrm{c}}$ & $2373^{\mathrm{c}}$ & $1692^{\mathrm{a}}$ & $4014^{\mathrm{d}}$ & $1641^{\mathrm{b}}$ & $4.80^{\mathrm{a}}$ & $83.30^{\mathrm{b}}$ \\
\hline \multirow{5}{*}{$\mathrm{R}$} & Native & $4144^{\mathrm{b}}$ & $2519^{\mathrm{b}}$ & $1625^{\mathrm{b}}$ & $4142^{\mathrm{c}}$ & $1623^{\mathrm{b}}$ & $4.53^{\mathrm{c}}$ & $80.70^{\mathrm{e}}$ \\
& $\mathrm{HMT}_{16}$ & $3382^{\mathrm{f}}$ & $2122^{\mathrm{e}}$ & $1260^{\mathrm{d}}$ & $3497^{\mathrm{f}}$ & $1375^{\mathrm{e}}$ & $4.53^{\mathrm{c}}$ & $81.55^{\mathrm{d}}$ \\
& $\mathrm{HMT}_{24}$ & $3297^{\mathrm{g}}$ & $2163^{\mathrm{e}}$ & $1134^{\mathrm{e}}$ & $3628^{\mathrm{e}}$ & $1465^{\mathrm{d}}$ & $4.53^{\mathrm{c}}$ & $80.80^{\mathrm{e}}$ \\
& $\mathrm{HMT}_{32}$ & $4405^{\mathrm{a}}$ & $2740^{\mathrm{a}}$ & $1665^{\mathrm{ab}}$ & $4603^{\mathrm{a}}$ & $1863^{\mathrm{a}}$ & $4.53^{\mathrm{c}}$ & $80.00^{\mathrm{f}}$ \\
\hline
\end{tabular}

C: Cultivar, MO: Modification, PV: Peak Viscosity (cP), TV: Trough Viscosity (cP), BV: Breakdown Viscosity (cP), FV: Final Viscosity (cP), SV: Setback Viscosity (cP), PT: Peak Time (mins.), PS: Pasting Temperature $\left({ }^{\circ} \mathrm{C}\right)$, W: White, R: Red, Values are means of triplicate determination, Mean values in the same column with different superscript are significantly different $(\mathrm{P} \leq 0.05)$
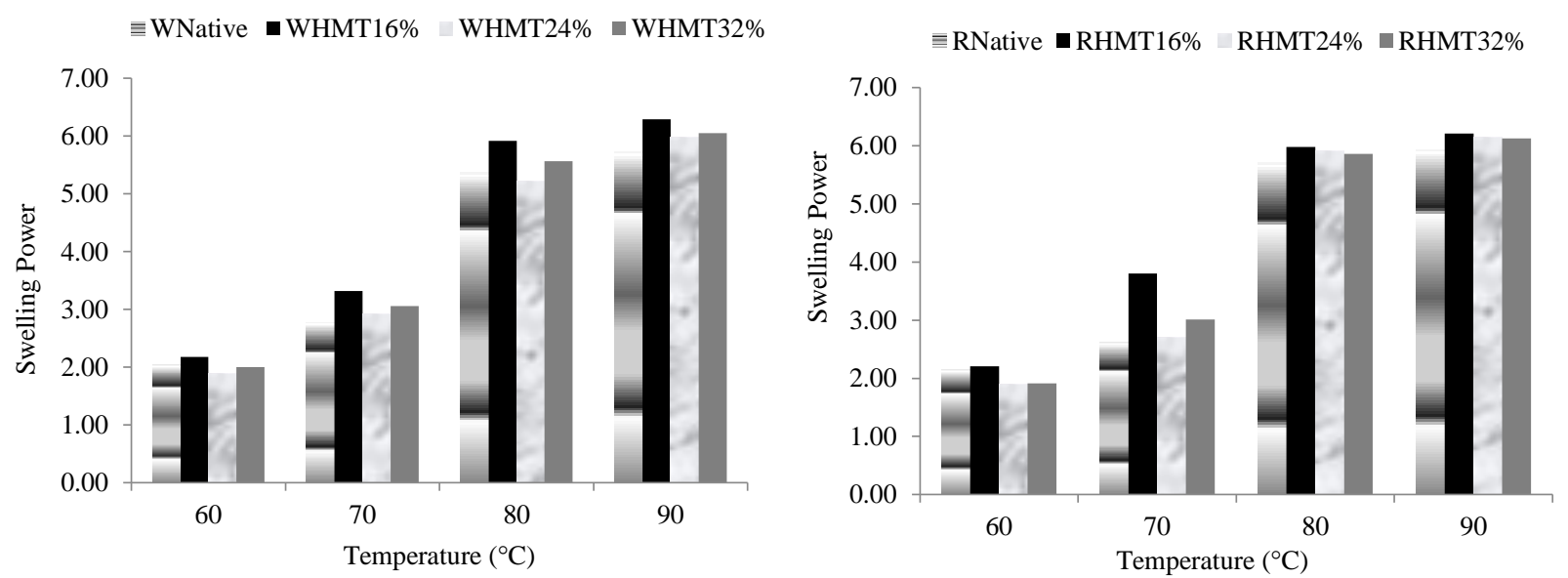

Figure 1. Effect of Temperature on the Swelling Power of Figure 2. Effect of Temperature on the Swelling Power of

Native and Heat Moisture Treated Starches of White Cocoyam

The extent of moisture level during the modification had variable effect on the hausner ratio and carr index of red cocoyam starch; at 24 and $32 \%$ moisture level both parameters were significantly increased suggesting a reduction in flowability and an improvement in compressibility (Igathinathane et al., 2010).

Pasting Properties of Starches of White and Red Cocoyam Varieties

The pasting properties of the native and heat moisture treated cocoyam starches are presented in Table 3. Pasting properties is very important to understand the utilization
Native and Heat Moisture Treated Starches of Red

Cocoyam

potential of starch and starchy samples. There were significant differences in the pasting properties of red and white cocoyam starches indicating differences in the molecular organization within the granules. The different level of moisture content during modification also affected the pasting properties. Peak viscosity is the maximum viscosity during the heating period; heat moisture treatment generally increased the peak viscosity of white cocoyam starches with modified sample at $16 \%$ moisture level having the highest (4390 cP). This same pattern of result was observed for trough viscosity and breakdown viscosity. This is contrary to the effect of heat moisture 
treatment on the peak viscosity of heat moisture treated rice starch as reported by Arns et al. (2015). Breakdown viscosity, which is the difference between peak viscosity and trough, indicates the extent to which the starch granules can withstand disintegration during heating and application of shear (Adebowale et al., 2005). Native starch had the lowest breakdown value, this suggest that the starch granules of native white cocoyam starch will be more resistant to disintegration and the paste would be more thermally stable than the modified white cocoyam starches. The high breakdown value of the modified sample may be due to high moisture content during heat treatment which might have enhanced the disruption of crystalline regions of starch granules and weakening of both intra and inter granular forces making the starch to be more susceptible to disintegration (Collado et al., 2001). Heat moisture treatment also increased the final viscosity and setback viscosity of white cocoyam starch; the high peak and final viscosity of white cocoyam starch may quality it as thickener in food applications. The ranges of peak time and pasting temperature for native and modified white cocoyam starch were 4.67 - 4.87 minutes and 81.65 $84.05^{\circ} \mathrm{C}$ respectively; heat moisture treatment caused a significant reduction in the pasting temperature of white cocoyam starch. This suggests that lesser forces and crosslinkings/interactions between adjacent amylopectin chains are present within the starch granules of heat moisture treated white cocoyam starch samples requiring lower thermal energy for granules disintegration and paste formation (Klein et al., 2013). This is reflected in the peak time, modified white cocoyam starch had lower peak time than native starch.

The pasting indices of native red cocoyam starch were significantly higher than that of native white cocoyam starch. This difference may be as a result of some factors which include difference in degree of crystalline packing within starch granules, associative forces between granules, and ratio of amylose and amylopectin. All these factors influence starch granules swelling and pasting (Xie et al., 2013; Tester and Morisson, 1990). The pasting properties of modified red cocoyam starch were moisture dependent. Modification at $16 \%$ and $24 \%$ moisture level reduced notable pasting properties of red cocoyam starch; however, at $32 \%$ moisture level these pasting properties were increased. This indicates that the level of moisture of starch granules played a significant role in the disorganization of amorphous and crystalline regions of the granules during heat moisture treatment. Red cocoyam starch modified at $24 \%$ moisture level had the lowest breakdown viscosity (1134 cP) amidst all the starch samples. This may be ascribed to the fact that at this moisture level heat moisture treatment increased the strength of links and interactions between the amylose and amylopectin resulting in a more stable structure (Arns et al., 2015). Paste of heat moisture treated red cocoyam starch at $24 \%$ would therefore have high mechanical and thermal stability and may be suitable for product that require long heating and stirring unit operations. The final viscosity (4603 cP) and setback viscosity (1863 cP) of heat moisture treated red cocoyam at $32 \%$ moisture level was the highest, such starch sample would be suitable for extruded products and stiff porridge however the retrogradation tendency will be high. The final viscosity, which indicates ability of starchy foods to form viscous paste after cooking and cooling, is an important parameter in predicting and defining the final textural quality of starch food (Arinola et al., 2016). Setback viscosity reflect the tendency of starch to retrograde, the higher the value the higher the retrogradation tendency (Sanni et al., 2004). Tendency of starch to retrograde is influenced by the size of starch granules, the presence of swollen non fragmented granules and the amount of leached amylose; all these affect the setback value (Lan et al., 2008). Heat moisture treatment had no effect on the peak time of red cocoyam starch however there was variation between the pasting temperature of native and modified red cocoyam starch which ranged from 80.00 to $81.55^{\circ} \mathrm{C}$.

\section{Conclusion}

Starch is a versatile material that is used in many industries for different purposes; it contributes to structure, texture and consistency of processed foods. Starch as a versatile raw material, has found different applications in diverse industries for different purposes; it has distinct potentials for contributing to structure, texture and consistency in numerous processed foods. Starch is also usually used as a thickener, an adhesive, encapsulating agent, gelling agent and binding agent. These diverse applications of starch endear it to food processors. In recent time, starch modification is increasingly becoming popular and widely employed in industries.

Most of the physicochemical properties of white and red cocoyam starches were affected by heat moisture treatment and the levels of moisture employed during the treatment. This study also provide information on the differential response of white and red cocoyam starches to the same modification conditions. Conclusively, the variable functional and pasting properties of the modified cocoyam starches can be exploited for relevant and suitable food and non food industrial applications.

\section{References}

Adebowale KO, Olu-Owolabi BI, Olayinka OO, Lawal OS. 2005. Effect of heat moisture treatment and annealing on physicochemical properties of red sorghum starch. African Journal of Biotechnology 4 (9): 928-933

AOAC. 2005. Official Methods of Analysis of the Association of Analytical Chemists $18^{\text {th }}$ edition. Association of Analytical Chemists, Washington D. C, USA

Aprianita A, Vasiljevic T, Bannikova A, Kasapi,s S. 2014. Physicochemical properties of flours and starches derived from traditional Indonesian tubers and roots. Journal of Food Science and Technology 51(12): 3669-3679

Arinola SO, Ogunbusola EM, Adebayo SF. 2016. Effect of Drying Methods on the Chemical, Pasting and Functional Properties of Unripe Plantain (Musa paradisiaca) Flour. British Journal of Applied Science \& Technology 14(3): 1-7

Arns B, Bartz J, Radunz M, do Evangelho JA, Pinto VZ, Zavareze ER, Dias ARG. 2015. Impact of heat-moisture treatment on rice starch, applied directly in grain paddy rice or in isolated starch. LWT - Food Science and Technology 60 (2015): 708 $-713$

Awokoya KN, Moronkola BA, Tovide OO. 2012. Characterization of starches from red cocoyam (Colocasia esculenta) and white cocoyam (Colocasia antiquorum) cormels. Food Science and Quality Management, 5: 27 - 35 
Chung HJ, Liu Q, Hoover R. 2009. Impact of annealing and heatmoisture treatment on rapidly digestible, slowly digestible and resistant starch levels in native and gelatinized corn, pea and lentil starches. Carbohydrate Polymers, 75: 436 - 447

Collado LS, Mabesa LB, Oates CG, Corke H. 2001. Bihontype noodles from heat moisture treated sweet potato starch. Journal of Food Science, 66: 604-609

Gbadamosi SO, Oladeji BS. 2013. Comparative studies of the functional and physico-chemical properties of isolated Cassava, Cocoyam and Breadfruit starches. International Food Research Journal, 20(5): 2273 - 2277

Himeda, M, Yanou NN, Nguimbou RM, Gaiani C, Scher J, Facho JB, Mbofung CMF. 2012. Physicochemical, rheological and thermal properties of taro (Colocassia esculenta) starch harvested at different maturity stages. International Journal of Biosciences (IJB), 2(3): 14-27

Igathinathane C, Jaya ST, Sokhansanj S, Bi X, Lim CJ, Melin S, Mohammad E. 2010. Simple and inexpensive method of wood pellets macro-porosity measurement. Bioresource Technology, 101(16): 6528-6537

Igbabul BD, Amove J, Twadue I. 2014. Effect of fermentation on the proximate composition, antinutritional factors and functional properties of cocoyam (Colocasia esculenta) flour. African Journal of Food Science and Technology 5 (3): 67 74

Kaur M, Oberoi DPS, Sogi DS, Gill BS. 2011. Physicochemical, morphological and pasting properties of acid treated starches from different botanical sources. Food Science and Technology, 48(4): 460-465

Klein B, Pinto VZ, Vanier NL, Zavareze ER, Colussi R., Evangelho JA, Gutkoski LC, Diasa ARG. 2013. Effect of single and dual heat-moisture treatments on properties of rice, cassava, and pinhao starches. Carbohydrate Polymers 98: $1578-1584$

Lan H, Hoover R, Jayakody L, Liu Q, Donner E, Baga M, Asare EK., Hucl P, Chibbar RN. 2008. Impact of annealing on the molecular structure and physicochemical properties of normal,waxy and high amylose bread wheat starches. Food Chemistry, 111(3): 663-675

Lu T-J, Lin J-H, Chen J-C, Chang Y-H. 2008. Characteristics of taro (Colocasia esculenta) starches planted in different seasons and their relations to the molecular structure of starch. Journal of Agricultural and Food Chemistry, 56, 2208-2215

Mirmoghtadaie L, Kadivar M, Shahedi M. 2009. Effects of crosslinking and acetylation on oat starch properties. Food Chemistry, 116: 709-713
Mpotokwane SM, Gaditlhatlhelwe E, Sebaka A, Jideani VA. 2008. Physical properties of bambara groundnuts from Botswana. Journal of Food Engineering, 89: 93 - 98

Nadir AS, Helmy IMF, Nahed MA, Wafaa MM, Ramadan M.T. 2015. Modification of Potato Starch by Some Different Physical Methods and Utilization in Cookies Production. International Journal of Current Microbiology and Applied Science 4 (10): 556 -569

Obiegbuna JE, Ishiwu CN, Akubor PI, Igwe EC. 2014. Effect of processing and storage relative humidity on selected functional properties of cocoyam (Colocasia esculenta) corm flour. Food Science and Quality Management 28: $19-28$

Oke MO, Awonorin SO, Workneh TS. 2013. Effect of varieties on physicochemical and pasting characteristics of water yam flours and starches. African Journal of Biotechnology, 12(11): $1250-1256$

Olayinka OO, Adebowale KO, Olu-Owolabi BI. 2007. Effect of heat-moisture treatment on physicochemical properties of white sorghum starch. Food Hydrocolloids, 2007. doi:10.1016/j.foodhyd.2006.11.004

Onitilo MO, Sanni LO, Daniel I, Maziya-Dixon B, Dixon A. 2007. Physicochemical and functional properties of native starches from cassava varieties in southwest Nigeria. Journal of Food, Agriculture and Environment 5 (3 \& 4): 108 - 114

Onwuka GI. 2005. Food Analysis and Instrumentation; Theory \& Practice. Lagos, Nigeria: Naphthali Prints, (Chapter 10)

Pinto VZ, Vanier NL, Deon VG, Moomand K, El Halal SLM, Zavareze ER, Lim L, Dias ARG. 2015. Effects of single and dual physical modifications on pinhao starch. Food Chemistry 187 2015: 98-105

Sanni LO, Kosoko SB, Adebowale AA, Adeoye RJ. 2004. The influence of palm oil and chemical modification on the pasting and sensory properties of fufu flour. International Journal of Food Properties. 7(2): 229-237

Sathe SK, Desphande SS, Salunkhe DK. 1982. Functional properties of lupin seed (Lupinus mutabilis) proteins and protein concentrates. Journal of Food Science, 47: 491-497

Tester RF, Morrison WR. 1990. Swelling and gelatinization of cereal starches: Effects of amylopectin, amylose and lipids. Cereal Chemistry, 67: 551-557

Xie Y, Yan M, Yuan S, Sun S, Huo Q. 2013. Effect of microwave treatment on the physicochemical properties of potato starch Granules. Chemistry Central Journal, 7(113): 1-7

Zavareze ER, Dias ARG. 2011. Impact of heat-moisture treatment andannealing in starches: A review. Carbohydrate Polymers, 83: 317-328 